\title{
Some Aspects of Good Practice for Safe Use of Wi-Fi, Based on Experiments and Standards
}

\author{
Imants Gorbāns $^{1 *}$, Aleksejs Jurenoks ${ }^{2}$ \\ ${ }^{1,2}$ Riga Technical University, Faculty of Computer Science and Information Technology, Riga, Latvia
}

\begin{abstract}
The aim of the research is to study the effect of microwave Wi-Fi radiation on humans and plants. The paper investigates national standards for permissible exposure levels to microwave radiation, measures electric field intensity and justifies the point of view regarding the safe use of microwave technologies based on multiple plant cultivation experiments at different distances from a Wi-Fi router. The results demonstrate that the radiation of $\mathrm{Wi}-\mathrm{Fi}$ routers significantly impairs the growth, development, yield and unexpected drought resistance of plants at short distances from the microwave source (up to $1 \mathrm{~m}$ to $2 \mathrm{~m}$; $-33 \mathrm{dBm}$ to $-43 \mathrm{dBm} ;>10 \mathrm{~V} / \mathrm{m})$. Slight effects are found up to about $4.5 \mathrm{~m}$ from a full-power home Wi-Fi router. As a result, suggestions are made for safe and balanced use of modern wireless technologies, which can complement occupational safety and health regulations.
\end{abstract}

Keywords - Electric field intensity, good practice, microwave, occupational safety, plants, router, standards, Wi-Fi.

\section{INTRODUCTION}

Microwaves are electromagnetic waves with a frequency of $0.3-1.0 \mathrm{GHz}$ to $300 \mathrm{GHz}$ and the corresponding wavelength from $1 \mathrm{~m}$ (in some sources $0.3 \mathrm{~m}$ ) to $1 \mathrm{~mm}$. Microwaves can be considered the shortest radio waves; however, more often this range is distinguished separately. If the term "radiation" is used, it should be noted that microwaves are non-ionizing radiation, but it affects inanimate objects and living organisms by warming them and affecting cell division processes.

Microwaves ranging from $1.8 \mathrm{GHz}$ to $2.45 \mathrm{GHz}$ are most widely used, and frequencies of $3.6 \mathrm{GHz}$ and higher are currently becoming topical. Common microwave technologies are as follows [2], [3]:

a) IEEE $802.11 / \mathrm{Wi}-\mathrm{Fi}: 2.45 \mathrm{GHz}$ and $5.8 \mathrm{GHz}$ (medium radiation);

b) Bluetooth: $2.45 \mathrm{GHz}$ (very low radiation);

c) microwave oven: $2.45 \mathrm{GHz}$ (very strong radiation);

d) mobile communications: $0.45 \mathrm{GHz}$ to $2.1 \mathrm{GHz}$ (moderate low radiation);

e) wireless sensor networks currently: $915 \mathrm{MHz}$ and $2.45 \mathrm{GHz}$ (weak, rare pulse emission);

f) $5 \mathrm{G}$ scheduled: $0.7 \mathrm{GHz}, 3.6 \mathrm{GHz} \ldots 28 \mathrm{GHz} \ldots$ (various solutions, possibly moderate low).

It is common practice to follow the recommendations on tanning time in ultraviolet rays, infrared sauna procedures, and now it is time to develop and incorporate recommendations for safe use of microwave radiation into occupational safety regulations.

\section{STUDIES AND NATIONAL STANDARDS FOR MICROWAVES}

Since the introduction of Wi-Fi in 1997, hundreds of scientific studies have been carried out around the world on the effects of microwaves on human health, but unfortunately there are no specific numerical recommendations for safe home and office use of W-Fi. The fact that for more than 10 years there are different national standards and guidelines with specific allowable doses (radiation power density $S, \mathrm{~W} / \mathrm{m}^{2}$ or electric field intensity $E, \mathrm{~V} / \mathrm{m}$, less often magnetic field induction $B$, $\mu \mathrm{T})$ demonstrates that these technologies are not absolutely safe, as is everything in this world. In addition, a distinction should be made between short-term and long-term exposure.

The World Health Organization has classified a Wi-Fi signal as a Class 2B carcinogen, i.e., it is not considered a direct potent carcinogen, but there is a reasonable point of view that there may be some risk, and we therefore need to carefully examine the relation between cell phones and cancer risk, continue to conduct research and monitor the situation [1].

Considering just a few of the many studies found in scientific article databases, it is worth noting that carcinogen, DNA, and sperm quality effects are the most frequently found publications on the given topic in medicine [8]. Research reveals that $2.45 \mathrm{GHz}$ radio frequency emissions from a Wi-Fi device affect testicular function and histology. The publication suggests avoiding long-term Wi-Fi radiation, especially for children and adolescents [11]. It should be noted that other studies have similar results [9].

One can find studies of rats that have been exposed to Wi-Fi for a long period. As a result, long-term irradiation has been found to have a minor effect on DNA damage, and it has been concluded that long-term exposure may pose a significant risk to DNA damage [7]. Other studies report similar results [10]. If a significant effect of microwaves of mobile communication frequency is observed on rodents, it may also have an effect on humans. One cannot ignore studies that long-term exposure to electromagnetic radiation from mobile phones and $\mathrm{Wi}-\mathrm{Fi}$ devices decreases plasma prolactin, progesterone, and estrogen levels but increases uterine oxidative stress in pregnant rats and their offspring [5].

\footnotetext{
* Corresponding author's e-mail: imants.gorbans@rtu.lv
} 
At Swinburne University of Technology, a study was conducted to test whether cell phone transmissions could affect the human brain. The researchers observed 120 healthy men and women with mobile phones attached to their heads. The data demonstrated that when the cell phone was in the transmission mode, the alpha wave activity was significantly increased in the brain, indicating that the cell phone produced an effect even though the cell phone power was low and within the allowable range [14]. Not to be surprised that not very strong electromagnetic signals can affect the functioning of the human brain, it should be noted that the human internal electrical signals are relatively weak.

It was found that sleeping close to a cell phone or in a house with Wi-Fi turned on, or in an apartment building with many full-power Wi-Fi signals turned on could lead to chronic sleep problems and even to depression or hypertension [4].

In Latvia, guidelines for electromagnetic radiation have been developed [13] in accordance with Directive 2013/25/EU of the European Parliament and of the Council [12]. Directives 2004 and 2013 of the European Parliament stipulate that in the range of $2.0 \mathrm{GHz}$ to $300 \mathrm{GHz}$ the magnetic field must not exceed $0.45 \mu \mathrm{T}$, but the power density should be $50 \mathrm{~W} / \mathrm{m}^{2}$ for a short period of time and $10 \mathrm{~W} / \mathrm{m}^{2}$ for a long period of time at a distance of $5 \mathrm{~cm}$. Transition from power (radiation) density to electric field intensity (strength): $1 \mathrm{~mW} / \mathrm{m}^{2} \geq 0.6 \mathrm{~V} / \mathrm{m} ; 1 \mathrm{~V} / \mathrm{m} \geq$ $2.65 \mathrm{~mW} / \mathrm{m}^{2}$. It is important that norms are frequency and exposure dependent: for higher frequencies, the admissible intensity is lower. There is an opinion that EU-certified devices do not violate the guidelines, but the question is raised whether the doses prescribed by the directive for all people do not affect their health and well-being, maybe the doses need to be reduced slightly, as the present study also indicates.

\section{ELECTRIC FIELD MEASUREMENTS}

Measurements were made using two devices of the Electromagnetic Radiation Tester, which, according to the manufacturer, measure the electric field intensity in the range of $1 \mathrm{~V} / \mathrm{m}$ to $1999 \mathrm{~V} / \mathrm{m}$ (with an error of $1 \mathrm{~V} / \mathrm{m}$ ) and in the frequency range of $5 \mathrm{~Hz}$ to $3500 \mathrm{MHz}$, the warning light and the LED signal turn on at $40 \mathrm{~V} / \mathrm{m}$. Measurements were made many dozens of times. The paper reports mean values or their range. Based on experience and experimentation with plants (see next chapter), we consider electric field intensity $E=10 \mathrm{~V} / \mathrm{m}$ to be permissible for prolonged exposure at $2.45 \mathrm{GHz}$. The most important results of the measurements made in this study are given in Table I and indicate the following regularities.

1. As can be seen, the cell phones used at a distance of $10 \mathrm{~cm}$ are within our defined norm of $10 \mathrm{~V} / \mathrm{m}$. Cell tower signals are significantly weaker $(<1 \mathrm{~V} / \mathrm{m})$.

2. Small office and household Wi-Fi routers are within our norm from a distance of $2 \mathrm{~m}$. It should be noted that the router radiation is the sum of the radiated microwave radiation $(\mathrm{GHz})$ and radiation of internal microcircuits such as the RISC processor (MHz), which is also accompanied by a pulse power supply of a few hundred $\mathrm{Hz}$ to a few dozen $\mathrm{MHz}$. In general, it can be stated that at a distance of $1 \mathrm{~m}$ all routers comply with the EU and Latvia guidelines; however, plants grow significantly worse at a distance of up to $2 \mathrm{~m}$, which we also consider as the smallest possible safe distance from Wi-Fi transmitters.

TABLE I

ELECTRIC FIELD INTENSITY FROM VARIOUS HOUSEHOLD IT AND ICT DEVICES

\begin{tabular}{|l|l|c|c|c|}
\hline No & Device & $d, \mathrm{~cm}$ & $\begin{array}{c}E, \\
\mathrm{~V} / \mathrm{m}\end{array}$ & Ok? \\
\hline 1. & $\begin{array}{l}\text { Smartphone with on screen without } \\
\text { Wi-Fi }\end{array}$ & 10 & $\sim 0$ & Yes \\
\hline 2. & $\begin{array}{l}\text { Smartphone with on screen and on } \\
\text { Wi-Fi } 2.45 \mathrm{GHz}\end{array}$ & 10 & $\sim 0-4 \ldots$ & Yes (No) \\
\hline 3. & Wi-Fi router, $2.45 \mathrm{GHz}$ & 30 & $40-110$ & No \\
\hline 4. & Wi-Fi router, 2.45 GHz & 100 & $30-60$ & No \\
\hline 5. & Wi-Fi router, 2.45 GHz & 200 & $\sim 0-4$ & Yes \\
\hline 6. & $\begin{array}{l}\text { Router pulse power supply } \\
(0.15 \mathrm{MHz} \text { to } 25 \mathrm{MHz})\end{array}$ & 10 & $70-180$ & No \\
\hline 7. & $\begin{array}{l}\text { Router pulse power supply }(0.15 \\
\text { MHz to 25 MHz) }\end{array}$ & 80 & $\sim 0$ & Yes \\
\hline 8. & $\begin{array}{l}\text { Cell tower antennas }(0.45 \mathrm{GHz} \ldots \\
\text { 2.1 GHz ...) }\end{array}$ & 10000 & $<1$ & Yes \\
\hline
\end{tabular}

\section{EXPERIMENTS ON THE EFFECTS OF W-FI ON PLANTS}

\section{A. Pilot Study With Different Plants In The Room}

As the authors had no desire to experiment with themselves, and did not want to bother animal rights activists, experiments were carried out using ordinary garden plants. The pilot study is scientific research in K12 physics "The Effects of Wi-Fi Router Microwave Radiation on Plants" conducted by the pupils of Baldone Secondary School in 2017 under supervision of the authors of this article. The authors thank pupils Lauris Dūzelis and Modris Vonda for their contribution to the implementation of research in practice.

On 22 September, the first rearing was started, planting 3 flowers (sunflowers, marigolds and asters) and 3 vegetables (tomatoes, beets, radishes) at 4 different distances from $\mathrm{Wi}-\mathrm{Fi}$ routers (the 5th was control planting in the next room). The seeds were sown in peat soil (no other fertilizer was used) in special seed trays and watered equally. The experiment was repeated twice, changing the location of the Wi-Fi routers to the opposite end of the room. Thus, 40 trays with 160 seeds were used ( 6 trays per windowsill in the first rearing and 4 - in the second). Two conventional home routers were used (Linksys WRT54G3G ver. 1.1 and Linksys WRT54G ver. 7). The window sashes, at which the plants were directly located, were not used for ventilation, and care was taken to ensure that all windows were used equally for ventilation.

From 13 to 20 October, the plants experienced an unexpected drought period (on school holidays), which gave the authors additional discovery - most of the plants withered but after watering they recovered, while the tomatoes being closest to the routers, which previously grew well (unlike other plants that grew slower near routers) did not recover and withered 
completely. On 27 October, the last measurements were made for the first rearing, but the second one took place from 10 November to 9 December, so the seedlings were grown twice for about one month.

Microwave radiation signal strength $I$ was measured using LinSSID, a wireless network monitoring software available on xUbuntu Linux, as well as control measurements were made using the WiFi Analyzer app for Android and Windows 10 Mobile operating systems. Due to slight fluctuations in the WiFi signal, LinSSID software was used to make 18 measurements at each plant location and mean values were used.

The following data were obtained: germination in the first attempt percentwise; the average length $(\mathrm{cm})$ of the aboveground parts of the plant before drought; ratio of plants that survived drought $(\%)$; the average length $(\mathrm{cm})$ of the aboveground parts of the plant at the end of the experiment; germination in the second attempt percentwise; the average length $(\mathrm{cm})$ of the above-ground parts of the plan; the average length of the root $(\mathrm{cm})$. The root lengths were not affected by radiation and were therefore not considered in subsequent calculations.
To combine the data of many measurements, the idea of factor analysis [7] was used: a mean value was calculated for each plant in a tray at a given period of time; windowsill 3 could be considered as the best growth result in all measurements (results of windowsill 4 were close to that of windowsill 3, but slightly worse, mainly due to tomatoes anomaly, plants D1-1); the ratio of the mean values of a particular plant for windowsills $1,2,4$ to the mean value for windowsill 3 was calculated $(\%)$; a mean value of all these data (\%) for each windowsill was calculated, which would also be considered a "growth factor" as average provided in Table II. Figure 1 uses the sum of intermediate results for better representation of all data.

The data of this method are provided in Table II, where, for example, P1-1 is the data for flower 1 in the first rearing, D1-2 is the data of vegetable 1 in the second rearing.

In the immediate vicinity of the routers $(0.4 \mathrm{~m}$ to $0.5 \mathrm{~m})$, seedlings grow $38 \%$ worse in the first month than at a distance of $4.5 \mathrm{~m}$ to $5 \mathrm{~m}$. Tomato seedlings did not survive a week-long drought, but the rest of the plants recovered, tomatoes are probably very sensitive plants. Wi-Fi radiation above $-45 \mathrm{dBm}$ can be considered harmless. These results correlate well with the results of the next experiment.

TABLE II

PILOT STUdy DATA AND THEIR COMBINATION IN GROWTH FACTOR

\begin{tabular}{|c|c|c|c|c|c|c|c|c|c|c|c|c|c|}
\hline $\begin{array}{c}\text { No } \\
\text { of } \\
\text { sill } \\
\end{array}$ & P1-1 & P2-1 & P3-1 & P1-2 & P2-2 & D1-1 & D2-1 & D3-1 & D1-2 & D2-2 & $\begin{array}{l}\text { Growth } \\
\text { factor as } \\
\text { average }\end{array}$ & $\begin{array}{c}\text { Distance, } \\
\mathrm{m}\end{array}$ & $I, \mathrm{dBm}$ \\
\hline 1. & 75 & 0 & 66 & 100 & 52 & 120 & 32 & 46 & 46 & 82 & 61.9 & $0.5-0.4$ & -29.8 \\
\hline 2. & 100 & 43 & 77 & 63 & 107 & 87 & 125 & 121 & 73 & 103 & 89.9 & $2.3-3.8$ & -43.5 \\
\hline 3. & 100 & 100 & 100 & 100 & 100 & 100 & 100 & 100 & 100 & 100 & 100.0 & $4.6-6.0$ & -45.9 \\
\hline 4. & 96 & 81 & 76 & 114 & 87 & 0 & 148 & 121 & 116 & 91 & 93.0 & 8.1 & -50.0 \\
\hline
\end{tabular}

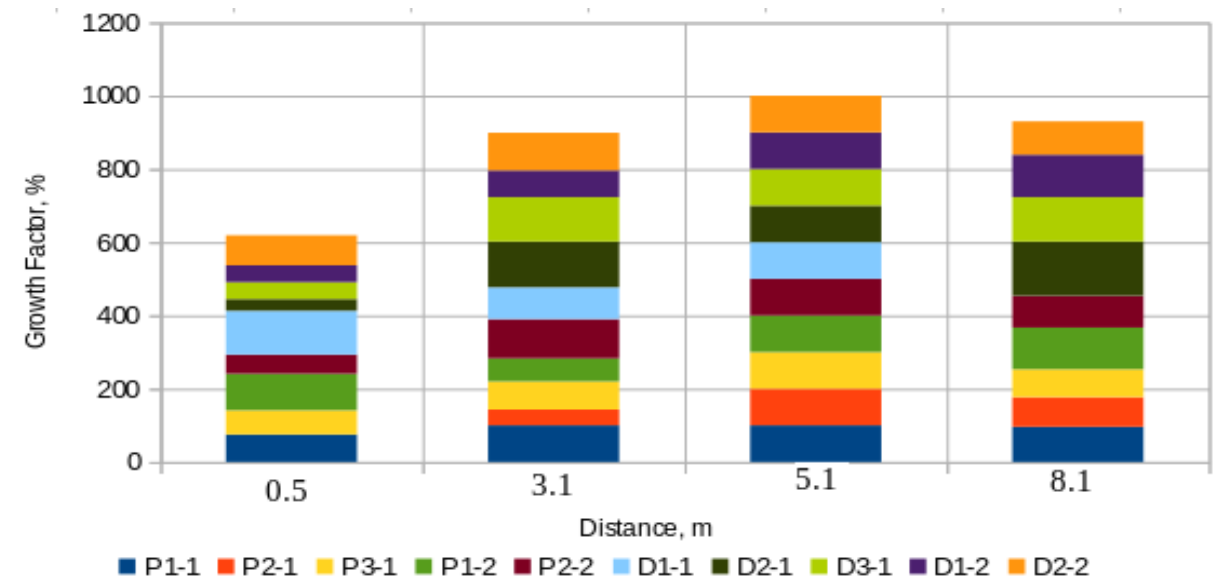

Fig. 1. Growth factor as the sum of intermediate results depending on distance to routers.

\section{B. Study of Cucumbers and Tomatoes in a Garden Hotbed}

In the summer of 2019, the first author of the study decided to strengthen the credibility of the results and created a $7 \mathrm{~m}$ long hotbed in his small garden in Inčukalns (Latvia) as better controlled environment with a Wi-Fi router running at one end for 6 weeks (Linksys WRT54G ver 7), but then it was removed allowing plants to grow freely for the next 6 weeks. On 20 June,
11 tomato and 15 cucumber seedlings were planted, almost identical in appearance. The same conditions of sunlight, watering, care and minimal fertilization were observed for all plants.

Unfortunately, the tomato yields were poor. Only the outermost tomatoes at a distance of $5.5 \mathrm{~m}$ from the Wi-Fi router produced well. However, the early stages of tomato growth were significant; in the first weeks seedlings at a distance of 
$0.5 \mathrm{~m}, 1 \mathrm{~m}, 1.5 \mathrm{~m}$ were slightly yellowish, with curved leaves, while the ones located farther from the router were green. The situation with yellowish tomatoes improved after fertilization.

The result of the study is believed to be the dependence of the number of grown cucumbers on the distance to the Wi-Fi router. The result is the number of cucumbers where a normal cucumber is 1 unit and a small cucumber is considered 0.5 units. By 15 September, a total of 49 cucumbers had grown in less than 3 months, including 4 small or half-cucumbers.

The main result of this experiment is the cucumber yield, which was initially (for the first 6 weeks) significantly lower near the Wi-Fi router than that of further seedlings. After removing the router for the next 6 weeks, the cucumbers that grew around it began to produce rapidly, but did not reach yields of cucumbers located farther.

As the number of cucumbers and tomatoes obtained varied slightly between adjacent seedlings, for the conclusions the hotbed was relatively divided into 3 zones -5 cucumber seedlings in each (see Table III). The data provided in Table III is graphically presented in Fig. 2. As one can easily see, the yield is worse at a distance of up to $2 \mathrm{~m}$ from a $2.45 \mathrm{GHz} \mathrm{Wi}-\mathrm{Fi}$ router turned on than that in the middle of the hotbed, while the best yield is observed for seedlings located farther than $4.5 \mathrm{~m}$. The router was turned on for the first 6 weeks, then it was removed and the crops were harvested after another 6 weeks (most yield was obtained by week 10).

TABLE III

SuMMARY OF THE NuMBER OF CUCUMBERS HARVESTED BY ZONE

\begin{tabular}{|c|c|c|c|c|}
\hline $\begin{array}{c}\text { Distance interval } \\
\text { from router } \\
l, \mathrm{~m}\end{array}$ & $\begin{array}{c}\text { Cucumber yield, } \\
\text { numbers after 6 weeks, } \\
\text { Wi-Fi On }\end{array}$ & $\begin{array}{c}\text { Cucumber additional } \\
\text { yield, numbers after Wi-Fi } \\
\text { Off }\end{array}$ & $\begin{array}{c}\text { Cucumbers yield } \\
\text { summary }\end{array}$ & $\begin{array}{c}\text { Wi-Fi signal strength } \\
\text { I, dBm }\end{array}$ \\
\hline 0 to 2 & 3 & 9 & 13 & -19 to -43 \\
\hline 2.5 to 4.5 & 6 & 8.5 & 14.5 & -45 to -50 \\
\hline 5 to 7 & 7 & 12.5 & 19.5 & -51 to -68 \\
\hline
\end{tabular}

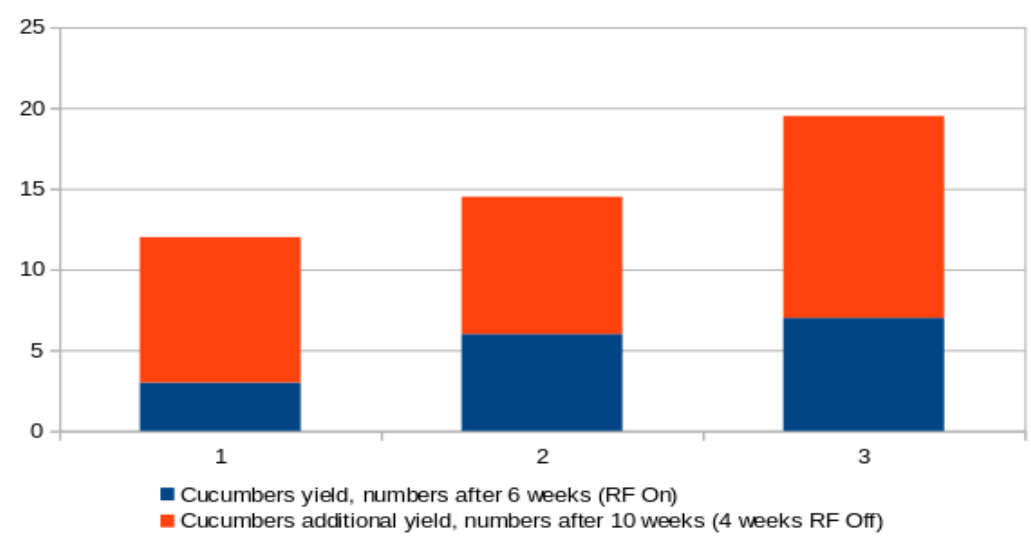

Fig. 2. Number of cucumbers by zone: Zone $1-0 \mathrm{~m}$ to $2 \mathrm{~m}$ from a Wi-Fi router, Zone $2-2.5 \mathrm{~m}$ to $4.5 \mathrm{~m}$, Zone $3-5 \mathrm{~m}$ to $7 \mathrm{~m}$.

The effects of microwaves on plants and humans are not identical, but these experiments indicate the effects of $2.45 \mathrm{GHz}$ microwaves on wildlife and suggest that it is unlikely that a person would be healthy where plants grow significantly worse. Both experiments show that the safe distance from a household Wi-Fi router working at full power is $4.5 \mathrm{~m}$ to $5 \mathrm{~m}$, but it is highly undesirable to be closer than $2 \mathrm{~m}$.

Norms, guidelines are probably good for an average person who has thick skin, good nutrition and regular physical activities. It is also important that the majority of existing hardware complies with specifications. If we want to adjust norms, then the most productive approach might not be to immediately set a lower allowable electric field intensity level, but to recommend placing the devices at a greater distance from long-term places of stay. The real impact on humans needs to be further studied, observed and analysed. It should also be taken into account that people have different levels of sensitivity, for example, some, as the authors of this study, may have a headache if a $\mathrm{Wi}-\mathrm{Fi}$ router is forgotten to be turned off in a room for some, e.g., 3 or 4 , days, while others may not feel any effect for 7 years. The infant has been observed to cry for no reason, but behind the wall there is a Wi-Fi transmitter or other source of radiation.

\section{CONCLUSION}

Conclusion 1. Further research is needed to more accurately and reasonably determine the allowable microwave radiation norms, it is possible that currently allowable norms may require a reduction in the future, as plants show poor growth and yield results not only in the close distance that does not meet the norms but also in the immediate areas to the radiation source, where radiation limits are not exceeded.

Conclusion 2. However, for now, the most productive approach might be not to immediately set a lower allowable electric field intensity level, but to recommend placing the devices at a greater distance from long-term places of stay. It is possible to specify certain distances: a full-power home wireless router is considered to be completely harmless to a living being if it is at least $4.5 \mathrm{~m}$ to $5 \mathrm{~m}$ away, but it is very 
harmful up to $2 \mathrm{~m}$. Thus, a Wi-Fi router should not be located on one's desk or nearby shelf.

Conclusion 3. It is useful to invite the public to adjust home wireless routers, access points, repeaters to lower power, such as $2 / 5$ or $3 / 5$ of the maximum; it is recommended to turn off routers when they are not in use; to hold cell phones at least 10 $\mathrm{cm}$ from the head during a call, hands-free devices are desirable. There is no reason to delay ICT progress, as meaningful and healthy use of Wi-Fi is possible if one is aware of the risks, formal norms and best practice recommendations provided in the present study.

\section{ACKNOWLEDGMENT}

This work has been supported by the European Regional Development Fund within the Activity 1.1.1.2 "Post-doctoral Research Aid" of the Specific Aid Objective 1.1.1 "To increase the research and innovative capacity of scientific institutions of Latvia and the ability to attract external financing, investing in human resources and infrastructure" of the Operational Programme "Growth and Employment" (No. 1.1.1.2/VIAA/1/16/043).

\section{REFERENCES}

[1] World Health Organization. IARC Classifies Radiofrequency Electromagnetic Fields as Possibly Carcinogenic to Humans, Press release No. 208, May 2011. Available: https://www.iarc.fr/wpcontent/uploads/2018/07/pr208_E.pdf. [Accessed: 12 December 2019].

[2] IEEE SA. IEEE-SA Standards Board Operations Manual. Available: https://standards.ieee.org/develop/policies/opman/ sect8.html. [Accessed: 12 December 2019].

[3] Liptai P., Moravec M., Badida M., "Analysis and Comparison of Electromagnetic Fields Radiated by the Selected Equipment," in $13^{\text {th }}$ GeoConference on Ecology, Economics, Education and Legislation, Slovakia, 2013, vol. 1, pp. 17-20. https://doi.org/10.5593/sgem2013/be5.v1/s20.003

[4] E-Group. 10 Shocking Facts about the Health Dangers of WiFi Global Health Center. Available: http://www.globalhealingcenter.com/naturalhealth/10-shocking-facts-health-dangers-wifi/. [Accessed: 12 December 2019].

[5] Yüksel M., Nazıroğlu M., Özkaya M. O., "Long-Term Exposure to Electromagnetic Radiation from Mobile Phones and Wi-Fi Devices Decreases Plasma Prolactin, Progesterone, and Estrogen Levels but Increases Uterine Oxidative Stress in Pregnant Rats and Their Offspring," Endocrine, vol. 52, iss. 2, pp. 352-362, May 2016. https://doi.org/10.1007/s12020-015-0795-3

[6] Rahn M., Factor Analysis: A Short Introduction, Part 1, The Analysis Factor. Available: http://www.theanalysisfactor.com/factor-analysis-1introduction/. [Accessed: 12 October 2019].
[7] Akdag M. Z., Dasdag S., Canturk F, Karabulut D., Caner Y., Adalier N., "Does Prolonged Radiofrequency Radiation Emitted from Wi-Fi Devices Induce DNA Damage in Various Tissues of Rats?" Journal of Chemical Neuroanatomy, vol. 75, pp. 116-122, Sep. 2016

https://doi.org/10.1016/j.jchemneu.2016.01.003

[8] Shokri S., Soltani A., Kazemi M., Sardari M., Mofrad M. B., "Effects of Wi-Fi (2.45 GHz) Exposure on Apoptosis, Sperm Parameters and Testicular Histomorphometry in Rats: A Time Course Study," Cell Journal, vol. 17, no. 2, pp. 322-331, 2015.

https://doi.org/10.22074/cellj.2016.3740

[9] Bhavanarayana B., Basha S. K., Manohar P., "Effects of Electromagnetic Waves on Male Reproduction," Int. J. of Pharm. Life Sci., pp. 39173926, Oct. 2014.

[10] Nazıroğlu M., Yüksel M., Köse S. A., Özkaya M. O., "Recent Reports of WiFi and Mobile Phone-Induced Radiation on Oxidative Stressand Reproductive Signaling Pathways in Females and Males," The Journal of Membrane Biology, vol. 246, no. 12, pp. 869-875, Oct. 2013. https://doi.org/10.1007/s00232-013-9597-9

[11] Dasdag S., Taș M., Akdag M.Z., Yegin K., "Effect of Long-Term Exposure of $2.4 \mathrm{GHz}$ Radiofrequency Radiation Emitted from Wi-Fi Equipment on Testes Functions," Electromagnetic Biology and Medicine, vol. 34, no. 1, pp. 37-42, Jan. 2014. https://doi.org/10.3109/15368378.2013.869752

[12] The European Council. Council Directive 2013/25/EU of 13 May 2013. Available: http://data.europa.eu/eli/dir/2013/25/oj. [Accessed: 12 December 2019].

[13] RSU. Vadlīnijas. Darba aizsardzības prasības nodarbināto aizsardzībai pret elektromagnētiskā lauka radīto risku darba vidē, Rīga, 2013.

[14] Douglas R. Mind control by cell phone. Scientific American, a Division of Springer Nature America, Inc., 2019.

https://www.scientificamerican.com/article/mind-control-by-cell/ [Accessed: 12 December 2019].

Dr. Imants Gorbāns is an Assistant Professor at University of Latvia and visiting assistant professor in Riga Technical University. He is the author of more than 20 publication and 4 teaching aids books. Imants research and passion is e-learning platforms, operating systems, open source software, physics didactics.

Phone: +371 29496831

E-mail: imants.gorbans@rtu.lv

Dr. Aleksejs Jurenoks is an associate professor at Riga Technical University faculty of Computer science and Information technology. His research interests include sensor network, adaptive and intelligent systems of information processing and applied systems. He is the author of 36 publications and 6 educational books. He is regularly involved in different EU-funded projects: eLOGMAR-M (FP6, 2004 -2006); IST4Balt (FP6, 2004 -2007), UNITE (FP6, 2006 - 2008) BONITA (INTERREG, 2008-2012). Phone: +371 29606250.

E-mail: aleksejs.jurenoks@rtu.lv ORCID iD:https://orcid.org/0000-0003-3187-6972 